УДК 633.11"324":631.5]:551.585.55(470.620)

06.00.00 Сельскохозяйственные науки

\section{ЭФФЕКТИВНОСТЬ ВЫРАЩИВАНИЯ РАЗ- ЛИЧНЫХ СОРТОВ ОЗИМОЙ ПШЕНИЦЫ В УСЛОВИЯХ ЗАПАДНОГО ПРЕДКАВКАЗЬЯ}

Квашин Александр Алексеевич

д-р с.-х. наук

РИНЦ SPIN - код 9812-7883

Горпинченко Ксения Николаевна

д-р экон. наук,

РИНЦ SPIN - код 340880

«Кубанский государственный аграрный университет имени И.Т. Трубилина», Краснодар, Россия

Нещадим Николай Николаевич

д-р с.-х. наук, профессор

РИНЦ SPIN - код8727-0250

neshhadim.n@kubsau.ru

«Кубанский государственный аграрный университет имени И.Т. Трубилина», Краснодар, Россия

Исследовано влияние типа севооборота, предшественника и различных доз минеральных удобрений на урожайность двух сортов озимой пшеницы (Лира и Краснодарская 99). Исследования проводили на Северо-Кубанской сельскохозяйственной опытной станции в двух десятипольных - зернопропашном и зернотравянопропашном севообороте длительного стационарного опыта. Почвачернозем обыкновенный, малогумусный мощный с содержанием гумуса, в зависимости от фонов питания в пахотном (0-30 см) слое почвы 3,954,00\%, минерального азота 5,9-8,3 мг/кг почвы, обменного калия 330-360 мг/кг почвы. Установлено, что максимальные величины элементов структуры урожая озимой пшеницы отмечено при системах удобрения с полным минеральным удобрением, минимальные - с использованием РК и NK. Урожайность озимой пшеницы зависит от севооборота $8-15 \%$; от предшественника - $15-18 \%$ и от удобрений 27-31\%. Качество зерна в основном определялась дозой удобрения. Повышенные и высокие дозы удобрений способствовали содержанию белка от 11,7 до 12,3 \% и клейковины 23,5-24,0\%. Установлена сильная корреляционная связь между урожайностью и агроприемами

КлючевЫе слова: ОЗИМАЯ ПШЕНИЦА, СОРТ, СЕВООБОРОТ, ПРЕДШЕСТВЕННИК, ДОЗА УДОБРЕНИЙ, СТРУКТУРА УРОЖАЙНОСТИ, УРОЖАЙ, КОЭФФИЦИЕНТ КОРРЕЛЯЦИИ
UDC 633.11"324":631.5]:551.585.55(470.620)

Agriculture

\section{EFFICIENCY OF CULTIVATION OF DIFFER- ENT WINTER WHEAT CULTIVARS IN THE CONDITIONS OF THE WEST CAUCASUS}

Kvashin Aleksandr Alekseevich

Dr. Agr. Sci.

SPIN: 9812-7883

Gorpinchenko Ksenija Nikolaevna

Dr. Ec. Sci.

SPIN: 340880

"Kuban State Agrarian University named after I.T.Trubilin», Krasnodar, Russia

Neshhadim Nikolay Nikolaevich

Dr. Agr. Sci., professor

SPIN: 8727-0250

neshhadim.n@kubsau.ru

Kuban State Agrarian University named after I.T.Trubilin, Krasnodar, Russia

The influence of the crop rotation type, predecessor and different doses of mineral fertilizers on the yield of two winter wheat cultivars (Lira and Krasnodar 99) was investigated. The investigations were carried out in the North-Kuban Agricultural Experiment Station in two five-crops: grain tillage and grain - grass tillage rotation of prolonged stationary experience. The soil is the black soil, low in humus, powerful, with humus content, depending on the power of nutrition backgrounds in the arable $(0-30 \mathrm{sm})$ soil layer is 3,95$4,00 \%$, of mineral nitrogen is $5,9-8,3 \mathrm{mg} / \mathrm{kg}$ of soil, of exchangeable potassium is $330-360 \mathrm{mg} / \mathrm{kg}$ of soil. It was found that the maximum value of the winter wheat crop structure elements is noticed in the fertilizer systems with complete mineral fertilizer, and the minimum value - with PK and NK. Winter wheat yield depends on the crop rotation of $8-15 \%$; from its predecessor $-15-18 \%$ and $27-31 \%$ of the fertilizer. Grain quality was generally determined by the dose of fertilizer. High and higher doses of fertilizers contributed to the protein content from 11.7 to $12.3 \%$ and fibrin content - 23,5-24,0\%. A strong correlation between yield and agronomic methods was determined

Keywords: WINTER WHEAT, CULTIVAR, CROP ROTATION, PREDECESSOR, FERTILIZER DOSE, YIELD STRUCTURE, YIELD, CORRELATION COEFFICIENT

\title{
Doi: 10.21515/1990-4665-123-081
}


Определяющим показателем, который в основном является и основным экономическим уровнем развития в регионе, является урожайность сельскохозяйственных культур [2, 5, 9, 11, 12, 34].

Урожайность колосовых культур - результат взаимодействия растений с окружающей средой и определяется в основном количеством продуктивных стеблей на единице площади и массой зерна с одного колоса, которая в свою очередь зависит от количества зерен в колосе и массы одной зерновки $[23,25,28]$.

Известно, что урожай злаков складывается из следующих компонентов: количества растений на единице площади, числа колосоносных стеблей на одном растении, количества зёрен в колосе, массы 1000 зёрен. При этом сбор зерна с гектара на 50 \% определяется плотностью продуктивного стеблестоя, на $25 \%$ - количеством зёрен в колосе и на $25 \%$ - массой 1000 семян.

В связи с большим разнообразием сортов и их биологической особенностью для различных почвенно-климатических зон и условий выращивания по данным А.А. Романенко, Л.А. Беспаловой [33] оптимум густоты продуктивного стеблестоя у сортов озимой пшеницы Краснодарской селекции варьирует в пределах 400-800 шт./м², Ростовской селекции - 500700 шт./м². К таким выводам пришли и многие другие исследователи [1, $27,31]$.

Одним из важнейших свойств озимой пшеницы, определяющим место её в севообороте, является реакция на изменение агрофона. Учитывая то, что среди злаковых культур, озимая пшеница наиболее требовательна к плодородию почвы, поэтому низкий агрофон является причиной снижения, а оптимальный - способствует повышению урожая зерна $[4,7,10,16,25$, $28,30,35,36]$.

Влияние удобрений на элементы продуктивности культуры и в целом на урожай многогранно. Недостаток любого из основных элементов 
питания особенно в первый месяц после появления всходов, отрицательно сказывается на числе колосков в колосе и цветков в них.

Дефицит азота в фазе кущения растений приводит к резкому уменьшению количества продуктивного стеблестоя, числа зёрен в колосе [26].

Наличие в растении механизма способствующего регулировать количество боковых побегов в зависимости от внешних условий, в конкретных почвенно-климатических зонах определяет необходимость разработки технологических приёмов, направленных на обеспечение оптимальных условий развития растений начиная с ранних фаз органогенеза.

Исследованиями в Центральной зоне Краснодарского края на выщелоченном чернозёме установлено, что по мере интенсификации приёмов возделывания культуры величина продуктивного стеблестоя возрастает на $28,9-40,5 \%[24,25,29]$.

В условиях новых экономических отношений перед сельскохозяйственным производством остро стала проблема эффективности производства зерна [5, 20, 21]. Данная проблема вызвана с возрастанием стоимости энергоносителей, сельскохозяйственной техники, средств защиты растений, удобрений. Объемы этих затрат значительно увеличиваются по мере интенсификации технологий $[6,8,18,22]$.

В связи с этими факторами применения удобрений, новой техники и технологий, введение новых сортов должно быть экономически выгодно и энергетически целесообразны $[13,17,23,33,35]$. Для разработки более прогрессивных энергосберегающих технологий и с учетом эффективности инноваций в зерновом производстве важна комплексная оценка с учетом агрономической, экономической и энергетической эффективности $[14,15$, $19,20,22,27]$.

Важным является также получение высококачественного зерна. Увеличение стабильности производства высококачественного зерна озимой пшеницы в значительной степени зависит от создания высокопродуктив- 
ных, высококачественных сортов, максимально адаптированных для экологических зон возделывания $[13,32,36]$. Даже при наличии хороших сортов необходимо знание агротехнических приёмов управления процессами, как формирования урожая, так и качества зерна, позволяющих наиболее полно реализовывать наследственный потенциал растений с учётом их биологических особенностей [3, 34].

Проблема сочетания высокой урожайности с хорошим качеством зерна остаётся одной из важных задач. Основными признаками высококачественного зерна остаются такие показатели как содержание белка и клейковины, которые определяют продовольственную и кормовую ценность зерна озимой пшеницы, а также технологические свойства муки, хлебопекарную, крупяную и кондитерскую её оценку.

Методика. Исследования проводились в северной зоне Краснодарского края. Почвы этого региона формируются в условиях теплого лета, сухой осени и нередко теплой зимы. Данные факторы способствуют активному разложению в почве органического вещества растительных остатков, образованию гуминовых веществ и распределению его по профилю почвы. Благоприятные водно-физические свойства чернозема обыкновенного способствуют хорошему сохранению осадков, увеличению активности микроорганизмов и улучшению питательного режима почвы.

Вместе с тем, черноземы обыкновенные отличаются невысоким содержанием гумуса 4,5-5,5\% характеризуются значительной мощностью гумусового горизонта. Количество общего азота находится в пределах 0,22-0,33\%, фосфора 0,16-0,19\%. Содержание калия в черноземе обыкновенном в 8-10 раз превышает запасы азота и фосфора.

Программой исследований предусматривалось изучение влияния вида севооборота, предшественника и систем удобрений на продуктивность озимой пшеницы и технологического качества товарной продукции. 
Исследования проводили в Северо-Кубанской сельскохозяйственной опытной станции в двух десятипольных севооборотах: зернопропашном (ЗП) и зернотравянопропашном (ЗТП). Чередование культур в ЗП: озимая пшеница - озимая пшеница - сахарная свекла - озимая пшеница - кукуруза на зерно - горох - озимая пшеница - подсолнечник - яровой ячмень кукуруза на зерно; в ЗТП: озимая пшеница - сахарная свекла - озимая пшеница - кукуруза на зерно - горох - озимая пшеница - подсолнечник яровой ячмень с подсевом под покров эспарцета - эспарцет (на семена) озимая пшеница.

Удобрение вносилось по следующей схеме: 1 - без удобрений (контроль); 2 - средняя доза РК $\left(\mathrm{P}_{60} \mathrm{~K}_{0}\right) ; 3$ - средняя доза $\mathrm{NK}\left(\mathrm{N}_{40} \mathrm{~K}_{0}\right) ; 4$ - средняя доза $\mathrm{NP}\left(\mathrm{N}_{40} \mathrm{~K}_{60}\right) ; 5$ - минимальная доза $\mathrm{NPK}\left(\mathrm{N}_{20} \mathrm{P}_{30} \mathrm{~K}_{0}\right) ; 6$ - средняя доза $\mathrm{NPK}\left(\mathrm{N}_{40} \mathrm{P}_{60} \mathrm{~K}_{0}\right) ; 7$ - повышенная доза $\mathrm{NPK}\left(\mathrm{N}_{80} \mathrm{P}_{120} \mathrm{~K}_{0}\right)$. Общая площадь делянки $190 \mathrm{~m}^{2}$, учетная - $108 \mathrm{~m}^{2}$. Повторность опыта четырехкратная.

Проведённые нами исследования в условиях недостаточного увлажнения северной зоны Краснодарского края показали, что за годы исследований величина продуктивного стеблестоя озимой пшеницы на единице площади посева также находилась в зависимости от изучаемых агроприемов и варьировала в пределах 423-685 шт./м². При этом определяющими факторами формирования продуктивного стеблестоя, исключая норму высева, были погодные условия, предшественники и уровень минерального питания.

Влияние предшественника на плотность продуктивного стеблестоя чётко просматривается на неудобренных контрольных вариантах.

Наибольшее количество продуктивных стеблей на естественном агрохимическом фоне питания в зернопропашном севообороте отмечено по

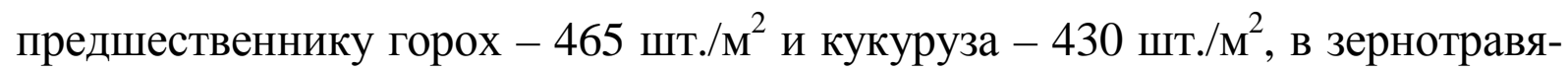
нопропашном - по эспарцету 502 шт./м² и гороху 485 шт./м² (таблицы 1, 2). 
Таблица 1 - Густота продуктивного стеблестоя озимой пшеницы в зернопропашном севообороте в зависимости от предшественника и системы удобрения, шт./м²

\begin{tabular}{|c|c|c|c|c|c|c|c|}
\hline Система удобрения & кукуруза & $\begin{array}{c}\text { озимая } \\
\text { пшеница }\end{array}$ & горох & $\begin{array}{c}\text { сахарная } \\
\text { свёкла }\end{array}$ & $\begin{array}{c}\text { Среднее } \\
\text { по системе } \\
\text { удобрения }\end{array}$ & ШТ./M ${ }^{2}$ & $\%$ \\
\hline Без удобрения (контроль) & 430 & 423 & 456 & 399 & 427 & & \\
\hline Средняя доза NK & 469 & 491 & 511 & 468 & 485 & +58 & 13,6 \\
\hline Средняя доза NP & 535 & 560 & 578 & 530 & 553 & +126 & 29,5 \\
\hline Минимальная доза NPK & 480 & 535 & 559 & 500 & 518 & +91 & 17,6 \\
\hline Высокая доза NPK & 611 & 651 & 622 & 594 & 629 & +202 & 47,3 \\
\hline Среднее по предшественнику & 522 & 555 & 566 & 524 & 543 & & \\
\hline
\end{tabular}


Таблица 2 - Густота продуктивного стеблестоя озимой пшеницы в зернотравянопропашном севообороте в зависимости от предшественника и системы удобрения, шт./м²

\begin{tabular}{|c|c|c|c|c|c|c|c|}
\hline \multirow{2}{*}{ Система удобрения } & \multicolumn{4}{|c|}{ Предшественник } & \multirow{2}{*}{$\begin{array}{l}\text { Среднее по } \\
\text { системе } \\
\text { удобрения }\end{array}$} & \multicolumn{2}{|c|}{ \pm к контролю } \\
\hline & Эспарцет & $\begin{array}{c}\text { озимая } \\
\text { пшеница }\end{array}$ & горох & $\begin{array}{c}\text { сахарная } \\
\text { свекла }\end{array}$ & & шт./M $\mathrm{M}^{2}$ & $\%$ \\
\hline Без удобрения (контроль) & 502 & 455 & 485 & 432 & 468 & & \\
\hline Средняя доза РК & 556 & 530 & 549 & 500 & 534 & +66 & 14,1 \\
\hline Средняя доза NK & 549 & 482 & 524 & 461 & 504 & +36 & 7,7 \\
\hline Средняя доза NP & 602 & 561 & 591 & 528 & 570 & +102 & 21,8 \\
\hline Минимальная доза NPK & 586 & 514 & 562 & 527 & 547 & +79 & 16,9 \\
\hline Средняя доза NPK & 635 & 610 & 628 & 599 & 618 & +150 & 32,0 \\
\hline Повышенная доза NPK & 675 & 629 & 642 & 629 & 645 & +177 & 41,5 \\
\hline Высокая доза NPK & 665 & 626 & 640 & 605 & 634 & +207 & 32,6 \\
\hline Среднее по предшественнику & 596 & 551 & 578 & 535 & 565 & & \\
\hline
\end{tabular}


Удобрения, внесённые в различных количествах и соотношении по элементам питания, соответственно севооборотам увеличивали, продуктивный стеблестой на 9-58 \%.

Дальнейшая интенсификация условий минерального питания до уровня повышенной $\left(\mathrm{N}_{40} \mathrm{P}_{40}, \mathrm{~N}_{80} \mathrm{P}_{60} \mathrm{~K}_{60}, \mathrm{~N}_{120} \mathrm{P}_{60} \mathrm{~K}_{60}\right)$ и высокой $\left(\mathrm{N}_{40} \mathrm{P}_{80}\right.$, $\left.\mathrm{N}_{80} \mathrm{P}_{120} \mathrm{~K}_{120}, \mathrm{~N}_{120} \mathrm{P}_{120} \mathrm{~K}_{120}\right)$ доз удобрений способствовала формированию более густого продуктивного стеблестоя 594-659 и 626-675 шт./м², что выше контрольного варианта на 47,3-49,4 и 32,6-41,5 \%, а в сравнении с минимальной дозой на 21,4-23,2 и 15,39-17,9 \%. Характерно то, что увеличение дозы фосфорно-калийных удобрений в 2 раза от средней не сопровождалось значительным возрастанием колосоносных стеблей.

Анализ полученных данных свидетельствует о том, что для формирования оптимального продуктивного стеблестоя озимая пшеница нуждается во всех элементах минерального питания. Применение только фосфорно-калийных удобрений по влиянию на величину продуктивного стеблестоя было выше относительно неудобренных вариантов на 13,0-24,3 и 10,8-16,5 \%, а в сравнении со средней дозой полного минерального удобрения этот показатель был меньше 72-177 и 79-90 шт./м² или на 14,8-33,6 и $14,2-19,8 \%$.

Недостаточная обеспеченность растений фосфором при систематическом исключении его из состава удобрений отрицательно сказывалось не только на содержании подвижных фосфатов в почве, но и на показателе, как общего, так и продуктивного кущения озимой пшеницы. При внесении только азотно-калийных удобрений количество продуктивных стеблей в сравнении с полным минеральным удобрением, внесённым в средних дозах, снижалось на 89-114, 86-138 стеблей на 1 м² или на 19,0-24,4 и 15,7$29,9 \%$. 
Исключение калия не отражалось на стеблеобразовании, в том числе и продуктивном, что можно объяснить высокой обеспеченностью обменным калием чернозёма обыкновенного.

Каждое повышение густоты продуктивного стеблестоя на 100 шт./м² увеличивает урожай зерна в среднем на 0,40 т/га. В наших исследованиях по мере увеличения плотности продуктивного стеблестоя на 100 шт./ м² величина урожая озимой пшеницы в зернопропашном севообороте возрастала на 0,14-0,94 и 0,15-0,42 т/га в зависимости от севооборота (рисунок 1). т/га

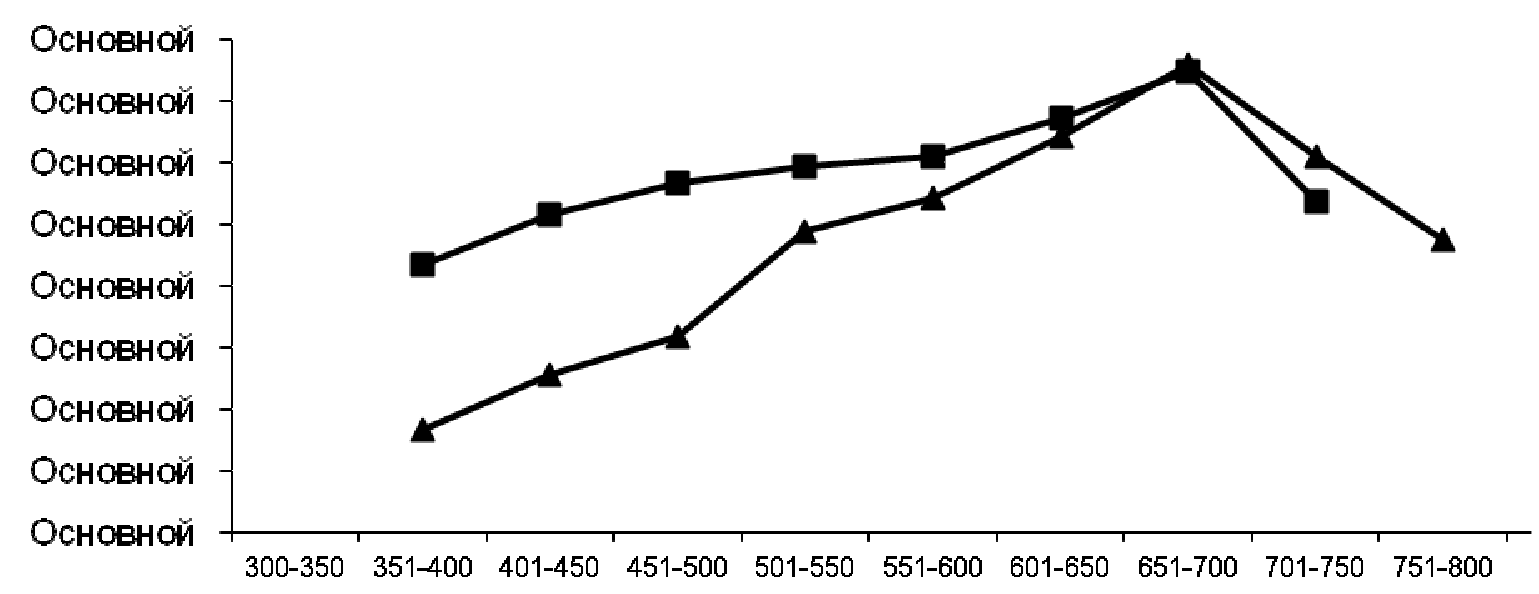

$\leftarrow$ зернопропашной севооборот $\rightarrow-$ зернотравянопропашной севооборот

Рисунок 1 - Влияние густоты продуктивного стеблестоя на урожайность зерна озимой пшеницы в различных севооборотах, т/га

При этом урожайность зерна возрастала до уровня плотности продуктивного стеблестоя 650-700 шт./м². Увеличение количества колосоносных стеблей выше этого показателя вело к снижению зерновой продуктивности, что видимо, связано с конкуренцией за влагу и питание.

Взаимосвязь плотности продуктивного стеблестоя на неудобренных вариантах выразилась уравнением $\mathrm{Y}=0,0335 \mathrm{x}+18,991$, на удобренных соответственно $\mathrm{y}=18,991+\mathrm{x}_{1}+0,0002 \mathrm{x}_{2}$ и $\mathrm{У}=0,0002 \mathrm{x}_{2}+0,258 \mathrm{x}_{1}-26,78$. 
Нами установлена тесная корреляционная связь между применяемыми системами удобрения и величиной продуктивного стеблестоя, а также между количеством продуктивных стеблей и урожайностью озимой пшеницы.

Наиболее устойчивый и высокий коэффициент корреляции 0,7050,877 и 0,873-0,943 по всем предшественникам между применяемыми дозами удобрений и продуктивным стеблестоем получен при использовании средней дозы полного минерального удобрения. Между плотностью продуктивного стеблестоя и величиной урожая отмечена также достаточно высокая корреляция ( $\mathrm{r}=0,750 \pm 0,097$ и $0,650 \pm 0,170)$.

Результаты регрессионного анализа позволили сделать выводы следующего порядка. Густота продуктивного стеблестоя на 23,5 \% определялась погодными условиями, на 43,2 и 52,7 \% системой удобрения.

Изучаемые технологические приёмы: севооборот, предшественники и системы удобрения влияли и на другие элементы продуктивности такие, как, количество зёрен в колосе, массу зерна с одного колоса, а также массу 1000 зерен.

У озимой пшеницы, также как и у всех зерновых колосовых культур, важной особенностью является компенсационная способность, которая заключается в возможности культуры посредством накопления запасов пластических веществ, компенсировать ущерб лимитирующих факторов среды, воздействующих на растения в ранние периоды вегетации за счет увеличения значений других элементов структуры урожая, закладывающихся в более поздние фазы развития.

Продуктивность колоса определяется не только количеством зерен в нем, но и массой зерна, и находится в зависимости от метеорологических условий, и от используемых агроприёмов.

Полученные нами данные свидетельствуют о том, что продуктивность одного колоса существенно меняется в зависимости от предшественника и удобрений (таблица 3). 
Таблица 3 - Влияние севооборота, предшественника и системы удобрения на массу зерна с одного колоса, г

\begin{tabular}{|c|c|c|c|c|c|c|c|}
\hline \multirow{3}{*}{$\begin{array}{c}\text { Система } \\
\text { удобрения }\end{array}$} & \multicolumn{4}{|c|}{ Предшественник } & \multirow{3}{*}{$\begin{array}{c}\text { Среднее } \\
\text { по систе- } \\
\text { ме удоб- } \\
\text { рения }\end{array}$} & \multirow{2}{*}{\multicolumn{2}{|c|}{$\begin{array}{l}\text { Прибавки } \\
\text { к контролю }\end{array}$}} \\
\hline & \multirow{2}{*}{$\begin{array}{l}\text { кукуруза, } \\
\text { эспарцет }\end{array}$} & \multirow{2}{*}{$\begin{array}{l}\text { озимая } \\
\text { пшеница }\end{array}$} & \multirow{2}{*}{ горох } & \multirow{2}{*}{$\begin{array}{c}\text { сахар- } \\
\text { ная } \\
\text { свёкла }\end{array}$} & & & \\
\hline & & & & & & $\Gamma$ & $\%$ \\
\hline \multicolumn{8}{|c|}{ зернопропашной севооборот } \\
\hline $\begin{array}{l}\text { Без удобрения } \\
\text { (контроль) }\end{array}$ & 0,71 & 0,90 & 0,96 & 0,78 & 0,84 & & \\
\hline Средняя доза РК & 0,81 & 0,93 & 1,05 & 0,78 & 0,89 & 0,05 & 5,9 \\
\hline Средняя доза NK & 0,88 & 1,01 & 0,96 & 0,87 & 0,93 & 0,09 & 10,7 \\
\hline Средняя доза NP & 1,05 & 1,05 & 1,05 & 0,99 & 1,03 & 0,19 & 22,6 \\
\hline $\begin{array}{l}\text { Минимальная } \\
\text { доза NPK }\end{array}$ & 0,90 & 0,95 & 0,96 & 0,88 & 0,92 & 0,08 & 9,5 \\
\hline Средняя доза NPK & 1,02 & 1,05 & 1,05 & 0,97 & 1,02 & 0,18 & 21,4 \\
\hline $\begin{array}{l}\text { Повышенная доза } \\
\text { NPK }\end{array}$ & 1,06 & 1,03 & 1,04 & 1,01 & 1,03 & 0,19 & 22,6 \\
\hline Высокая доза NPK & 1,06 & 0,96 & 1,02 & 1,05 & 1,02 & 0,18 & 21,4 \\
\hline $\begin{array}{l}\text { Среднее по } \\
\text { предшественнику }\end{array}$ & 0,94 & 0,98 & 1,01 & 0,92 & & & \\
\hline \multicolumn{8}{|c|}{ зернотравянопропашной севооборот } \\
\hline $\begin{array}{l}\text { Без удобрения } \\
\text { (контроль) }\end{array}$ & 1,09 & 0,91 & 0,96 & 0,82 & 0,94 & & \\
\hline Средняя доза РК & 1,03 & 0,95 & 1,03 & 0,86 & 0,97 & 0,03 & 3,2 \\
\hline Средняя доза NK & 1,02 & 0,98 & 0,97 & 0,95 & 0,98 & 0,04 & 4,2 \\
\hline Средняя доза NP & 1,05 & 0,98 & 1,00 & 1,08 & 1,03 & 0,09 & 9,6 \\
\hline $\begin{array}{l}\text { Минимальная } \\
\text { доза NРК }\end{array}$ & 1,09 & 1,02 & 0,98 & 0,86 & 0,99 & 0,05 & 5,3 \\
\hline Средняя доза NPK & 1,03 & 1,04 & 1,00 & 1,01 & 1,02 & 0,08 & 8,5 \\
\hline $\begin{array}{l}\text { Повышенная доза } \\
\text { NPK }\end{array}$ & 0,97 & 1,05 & 1,02 & 1,01 & 1,01 & 0,07 & 7,4 \\
\hline Высокая доза NPK & 1,00 & 0,95 & 1,02 & 1,01 & 0,99 & 0,05 & 5,3 \\
\hline $\begin{array}{l}\text { Среднее по } \\
\text { предшественнику }\end{array}$ & 1,03 & 0,98 & 1,00 & 0,95 & & & \\
\hline
\end{tabular}


На естественном агрохимическом фоне минерального питания контрольных вариантов, в зависимости от предшественника масса зерна с колоса различалась на 0,07-0,25 г в зернопропашном и 0,13-0,27 г в зернотравянопропашном севообороте. Более полновесное зерно формировалось по предшественникам эспарцет - 1,09 г, горох - 0,96 г и озимая пшеница 0,9 г. Самое легковесное 0,71 г - получено по предшественнику кукурузе. По мере улучшения условий минерального питания этот показатель структуры урожая изменялся в сторону увеличения в зернопропашном севообороте на 5,9-22,6 \%, в севообороте с травами - на 3,2-9,6 \%.

Улучшение условий минерального питания, на фоне сложившегося за долгие годы существования стационарного опыта почвенного плодородия, увеличивало массу зерна с одного колоса при внесении минимальной дозы удобрения в зависимости от предшественника $\left(\mathrm{N}_{10} \mathrm{P}_{20}\right.$, $\left.\mathrm{N}_{20} \mathrm{P}_{30} \mathrm{~K}_{30}, \mathrm{~N}_{30} \mathrm{P}_{30} \mathrm{~K}_{30}\right)$ на 0,05-0,19 и 0,02-0,11 г или 5,5-19,0 и 2,1-12,2 \%. При этом по результатам исследований максимальной она была при размещении озимой пшеницы по предшественникам эспарцет 0,85-1,29 г, озимая пшеница $0,82-1,02$ и 0,85-1,24 г и горох - 0,80-1,24 и 0,85-1,37 г. На вариантах со средней дозой полного минерального удобрения масса зерна с одного колоса соответствовала по этим предшественникам - 0,85 -1,33 г, 0,95-1,12 и 1,03-1,06 г, 0,92-1,28 и 0,89-1,20 г, что выше относительно контрольного варианта в среднем на 8,5 - 21,4\%, а в сравнении с минимальной дозой - на 3,0 - 10,8 \%. На вариантах с повышенной $\left(\mathrm{N}_{40} \mathrm{P}_{40}, \mathrm{~N}_{80} \mathrm{P}_{60} \mathrm{~K}_{60}, \mathrm{~N}_{120} \mathrm{P}_{60} \mathrm{~K}_{60}\right)$ и высокой $\left(\mathrm{N}_{40} \mathrm{P}_{80}, \mathrm{~N}_{80} \mathrm{P}_{120} \mathrm{~K}_{120}, \mathrm{~N}_{120} \mathrm{P}_{120} \mathrm{~K}_{120}\right)$ дозами удобрения масса зерна с одного колоса соответственно севооборотам превышала контроль на 22,6-21,4 и 7,4-5,3 \%. Несколько меньшая масса зерна 0,96-1,06 и 0,95-1,01 г сформированная при интенсивных дозах удобрения, объясняется повышенной кустистостью, при которой развивалось большее количество боковых побегов сформировавших более мелкое зерно. 
Исключение из состава удобрений азота и фосфора снижало весовую продуктивность колоса, в сравнении со средней дозой полного минерального удобрения, на 14,6-9,7 и 5,1-4,1 \% или на 0,13-0,09 и 0,05-0,04 г.

При некотором снижении массы зерна с колоса на вариантах с высокой дозой удобрений получен практически одинаковый урожай озимой пшеницы с вариантом при повышенной дозе. Насыщение удобрений фосфорно-калийными туками в два раза от среднего на этом варианте не способствовало формированию крупного зерна.

По мере интенсификации условий выращивания масса зерна с колоса возрастает, определяя величину урожая, о чем свидетельствует коэффициент парной корреляции между урожайностью и массой зерна с колоса на неудобренных вариантах составил $0,359 \pm 0,139$ и на удобряемых 0,605 $\pm 0,170$.

Математическая обработка данных методом корреляционнорегрессионного анализа показала наличие прямой положительной связи между урожайностью озимой пшеницы и слагающими её элементами с коэффициентом множественной корреляции 0,987-0,999 (таблица 4).

Наибольшее влияние на величину урожайности озимой пшеницы оказывало количество продуктивных стеблей 30,9-77,8 \%, при этом максимальные значения этого показателя были при размещении озимой пшеницы по предшественникам озимая пшеница и горох, минимальные - по кукурузе убираемой на зерно.

Доля влияния продуктивности колоса составила 19,41-34,7 \%. Масса 1000 зёрен имела наименьшее значение, что свидетельствует о слабой изменчивости этого показателя структуры урожая от воздействия изучаемых агроприёмов.

Таким образом, изучаемые приёмы технологии возделывания озимой пшеницы оказывали неодинаковое влияние на формирование элементов структуры урожая и, в конечном итоге, на урожайность зерна. Возделыва- 
ние озимой пшеницы без применения удобрений обеспечивало минимальное количество продуктивных стеблей. Большая доля влияния на показатели продуктивности посева достигались под влиянием удобрений.

Таблица 4 - Регрессионный анализ влияния элементов структуры урожая на зерновую продуктивность озимой пшеницы при возделывании по различным предшественникам

\begin{tabular}{|c|c|c|c|c|c|c|}
\hline \multirow{2}{*}{$\begin{array}{l}\text { Предше- } \\
\text { ственник }\end{array}$} & \multicolumn{4}{|c|}{ Доля влияния, \% } & \multirow[t]{2}{*}{$\mathrm{R}$} & \multirow{2}{*}{$\begin{array}{c}\text { Уравнение множественной } \\
\text { регрессии }\end{array}$} \\
\hline & A & $\mathrm{B}$ & $\mathrm{C}$ & Д & & \\
\hline \multicolumn{7}{|c|}{ зернопропашной севооборот } \\
\hline Кукуруза & 9,25 & 50,6 & 34,68 & 3,76 & 0,996 & $\begin{array}{l}\mathrm{Y}=-8,225+\mathrm{X}_{2} 0,0462+ \\
\mathrm{X}_{3} 0,0099+\mathrm{X}_{4} 3,502+\mathrm{X}_{5} 0,461\end{array}$ \\
\hline $\begin{array}{l}\text { Озимая } \\
\text { пшеница }\end{array}$ & 8,97 & 58,0 & 29,10 & 3,41 & 0,997 & $\begin{array}{l}\mathrm{Y}=-6,070-\mathrm{X}_{2} 0,007+ \\
\mathrm{X}_{3} 0,009+\mathrm{X}_{4} 6,951+\mathrm{X}_{5} 0,048\end{array}$ \\
\hline Горох & 2,32 & 70,43 & 20,31 & 0,71 & 0,989 & $\begin{array}{l}\mathrm{Y}=-5,245+\mathrm{X}_{1} 0,008+ \\
\mathrm{X}_{2} 0,0045+\mathrm{X}_{3} 3,581+\mathrm{X}_{4} 0,075\end{array}$ \\
\hline $\begin{array}{l}\text { Сахарная } \\
\text { свёкла }\end{array}$ & 8,77 & 53,15 & 33,04 & 5,28 & 1,000 & $\begin{array}{l}\mathrm{Y}=-0,205-\mathrm{X}_{1} 0,007+ \\
\mathrm{X}_{2} 0,012+\mathrm{X}_{3} 5,174-\mathrm{X}_{4} 0,083\end{array}$ \\
\hline \multicolumn{7}{|c|}{ зернотравянопропашной севооборот } \\
\hline Эспарцет & 35,94 & 30,39 & 24,74 & 6,43 & 0,987 & $\begin{array}{l}\mathrm{Y}=-10,245+\mathrm{X} 1_{2} 0,019+ \\
\mathrm{X}_{2} 0,0042+\mathrm{X}_{3} 3,558+\mathrm{X}_{4} 0,055\end{array}$ \\
\hline $\begin{array}{l}\text { Озимая } \\
\text { пшеница }\end{array}$ & 1,32 & 77,80 & 19,41 & 0,66 & 0,996 & $\begin{array}{l}\mathrm{Y}=-3,555+\mathrm{X}_{1} 0,005+ \\
\mathrm{X}_{2} 0,0085+\mathrm{X}_{3} 4,297+ \\
\mathrm{X}_{4} 0,0075\end{array}$ \\
\hline Горох & 2,54 & 76,58 & 20,10 & 0,58 & 0,997 & $\begin{array}{c}\mathrm{Y}=-4,281+\mathrm{X}_{1} 0,009+ \\
\mathrm{X}_{2} 0,0055+\mathrm{X}_{3} 3,658+\mathrm{X}_{4} 0,055\end{array}$ \\
\hline $\begin{array}{l}\text { Сахарная } \\
\text { свёкла }\end{array}$ & 10,27 & 57,63 & 31,23 & 0,44 & 0,999 & $\begin{array}{c}\mathrm{y}=-3,571+\mathrm{X}_{1} 0,061+ \\
\mathrm{X}_{2} 0,116+\mathrm{X}_{3} 5,345+\mathrm{X}_{4} 0,0087\end{array}$ \\
\hline
\end{tabular}

Примечание: А - густота стояния растений, шт./м²;

В - плотность продуктивного стеблестоя, шт./M²;

С - масса зерна с колоса, г;

Д-масса 1000 зёрен, г. 
Современные сорта озимой пшеницы Краснодарской селекции относятся к высокопродуктивным сортам способным формировать урожайность на уровне 9,0-10,0 т/га с высоким качеством зерна. Однако в условиях производства не всегда реализуется потенциальная их продуктивность, ввиду несоответствия условий выращивания с биологическими требованиями культуры.

Обобщенные результаты исследований показали, что метеорологические условия, приёмы возделывания озимой пшеницы, минеральное питание являются основополагающими в формировании всех элементов структуры определяющих величину урожая и валовых сборов зерна. При этом удобрение - одно из наиболее эффективных и быстродействующих средств. Его эффективность зависит от уровня плодородия почвы, погодных условий и предшественника по которому размещаются посевы озимой пшеницы.

Анализ наших данных позволил также отметить значительное варьирование урожайности озимой пшеницы в различных севооборотах по предшественникам соответственно и изучаемым системам удобрения, но уже в северной зоне края. Диапазон варьирования сбора зерна с гектара на неудобренных контрольных вариантах находился в пределах: по предшественнику кукуруза - 2,55-3,21 по озимой пшенице соответственно севооборотам - 3,14-4,36 и 3,31-5,17, по гороху - 3,55-5,72 и 2,64-5,77, сахарной свёкле - 2,43-4,10 и 2,64-4,70. Самая высокая зерновая продуктивность озимой пшеницы на естественном фоне питания получена при размещении её по предшественнику эспарцет, убираемому на семена - 3,49-6,58 т/га. Средний за семь лет показатель урожайности зерна по данному предшественнику - 5,41 т/га, что в 1,3-1,9 раза превышал уровень урожайности полученный по другим предшественникам.

Выявлена различная реакция озимой пшеницы на несбалансированность удобрений по элементам минерального питания (таблица 5). 
Таблица 5 - Урожайность озимой пшеницы в различных севооборотах в зависимости от предшественника и систем удобрений с парным сочетанием по элементам минерального питания, т/га

\begin{tabular}{|c|c|c|c|c|c|c|c|}
\hline \multirow{2}{*}{$\begin{array}{c}\text { Система } \\
\text { удобрения }\end{array}$} & \multicolumn{4}{|c|}{ Предшественник } & \multirow{2}{*}{$\begin{array}{c}\text { Среднее } \\
\text { по си- } \\
\text { стеме } \\
\text { удобре- } \\
\text { ния }\end{array}$} & \multicolumn{2}{|c|}{$\begin{array}{l}\text { Отклонение } \\
\text { от контроля }\end{array}$} \\
\hline & $\begin{array}{r}\text { кукуруза, } \\
\text { эспарцет }\end{array}$ & $\begin{array}{c}\text { озимая } \\
\text { пшеница }\end{array}$ & горох & $\begin{array}{l}\text { сахарная } \\
\text { свёкла }\end{array}$ & & т/га & $\%$ \\
\hline \multicolumn{8}{|c|}{ зернопропашной севооборот } \\
\hline $\begin{array}{l}\text { Без удобрений } \\
\text { (контроль) }\end{array}$ & 2,85 & 3,58 & 4,41 & 3,05 & 3,47 & & \\
\hline Средняя доза РК & 3,59 & 4,62 & 5,64 & 3,60 & 4,36 & 0,89 & 25,6 \\
\hline Средняя доза NK & 4,00 & 4,74 & 4,96 & 4,60 & 4,57 & 1,10 & 31,7 \\
\hline Средняя доза NP & 5,17 & 5,71 & 6,00 & 5,15 & 5,51 & 2,04 & 58,5 \\
\hline $\mathrm{HCP}_{05}$ & 0,39 & 0,41 & 0,55 & 0,41 & & & \\
\hline $\begin{array}{l}\text { Без удобрений } \\
\text { (контроль) }\end{array}$ & 5,41 & 4,11 & 4,65 & 3,34 & 4,38 & & \\
\hline Средняя доза РК & 6,09 & 5,08 & 5,68 & 4,04 & 5,22 & 0,84 & 18,9 \\
\hline Средняя доза NK & 5,43 & 4,67 & 5,08 & 4,25 & 4,86 & 0,48 & 11,0 \\
\hline Средняя доза NP & 5,99 & 5,34 & 5,76 & 5,53 & 5,65 & 1,27 & 29,0 \\
\hline $\mathrm{HCP}_{05}$ & 0,50 & 0,50 & 0,53 & 0,40 & & & \\
\hline
\end{tabular}

Более высокими прибавками урожая данная культура реагировала на внесение средних, соответственно предшественникам, доз азотнофосфорных удобрений. При внесении $\mathrm{N}_{20} \mathrm{P}_{40}$ по предшественникам эспарцет и горох прибавка зерна относительно контрольного варианта составила 0,58; 1,59 и 1,11 т/га. По предшественникам кукуруза и озимая пшеница при внесении $\mathrm{N}_{60} \mathrm{P}_{60}$ прибавки в среднем составили 2,3; 2,13-1,23 т/га, а по сахарной свёкле применение $\mathrm{N}_{40} \mathrm{P}_{60}$ обеспечило рост урожайности $-2,10$ 2,19 т/га. Исключение калия из состава удобрения снизило зерновую продуктивность озимой пшеницы на 0,38-0,28 т/га.

Применение только фосфорных удобрений $\left(\mathrm{P}_{40}\right)$ по предшественникам эспарцет и горох обеспечило прибавку урожая, относительно кон- 
трольного варианта 0,$68 ; 1,20-1,03$ т/га, а в процентном выражении на 12,6 и $27,2-22,1 \%$. Внесение фосфорно-калийных удобрений в дозе $\mathrm{P}_{60} \mathrm{~K}_{60}$ по предшественникам кукуруза, озимая пшеница и сахарная свёкла способствовала росту урожайности относительно неудобренного фона на 0,74 ; $1,04-0,55$ и 0,97-0,70 т/га. Недобор урожая при исключении из состава удобрений азота, в сравнении со средней дозой полного минерального удобрения в зернопропашном севообороте составил 1,52 т/га, в зернотравянопропашном - 0,72 т/га или 25,8-12,4\%.

Полученные данные свидетельствуют о том, что в севообороте с травами, где $20 \%$ озимой пшеницы размещается по бобовым предшественникам, благотворно влияющим на азотный режим почвы, урожайность озимой пшеницы при данных системах удобрения выше на 0,86 т/га. Более чувствительна озимая пшеница к недостатку азота при размещении по кукурузе и сахарной свёкле. По этим предшественникам получен самый высокий недобор урожая 1,97 и 1,93-1,63 т/га. По колосовому предшественнику значительное снижение урожая отмечено в зернопропашном севообороте 1,50 т/га, при 0,47 - в севообороте с травами, где озимая пшеница продуктивно использовала оборот пласта эспарцета.

Самая высокая отрицательная реакция на исключение из состава удобрений фосфора отмечена по предшественникам кукуруза - 1,56 т/га и сахарная свёкла 1,52-1,42 т/га. Значительным недобором зерна в зернопропашном севообороте 1,38 т/га на недостаточную обеспеченность фосфором реагировала озимая пшеница при размещении по гороху и колосовому предшественнику.

Полученные урожайные данные показали большую значимость всех основных элементов минерального питания в формировании урожая озимой пшеницы. В отдельные годы разница в урожае с единицы площади при исключении этих элементов питания из состава удобрений достигала 2,59 т/га. 
Несмотря на высокую обеспеченность чернозёма обыкновенного обменным калием при систематическом исключении этого элемента питания из состава удобрений влечёт за собой снижение урожайности озимой пшеницы, достигая в отдельные годы величиной от 1,08-1,29 т/га.

Улучшение условий минерального питания, за счёт внесения сбалансированных по всем элементам доз удобрений способствовало получению достаточно высокого урожая (таблица 6).

При применении минимальных доз полного минерального удобрения величина урожая зерна озимой пшеницы с одного гектара возрастала в зернопропашном севообороте до 4,70 т/га в т.ч. по предшественникам от 4,07 до 5,38 т/га, в зернотравянопропашном согласно размещению в севообороте от 4,43 до 6,17 т/га, при среднем показателе 5,28 т/га. Прирост урожайности при использовании данной системы удобрения в среднем за годы изучения составил 0,90-1,23-т/га или 20,5\%-35,4\% в сравнении с контрольными вариантами.

Увеличение доз удобрения до уровня $\mathrm{N}_{20} \mathrm{P}_{40}, \mathrm{~N}_{40} \mathrm{P}_{60} \mathrm{~K}_{60}$ и $\mathrm{N}_{60} \mathrm{P}_{60} \mathrm{~K}_{60}$, то есть в 2 раза от минимальной, обеспечило получение урожая озимой пшеницы в пределах 5,52-6,31 и 5,55-6,36 т/га при среднем показателе по данной системе удобрения 5,88-5,93 т/га. В сравнении с контрольным вариантом прибавка здесь соответственно севооборотам составила 2,41-1,85 т/га или 69,4-35,4\%, а с минимальной дозой прирост урожая был на уровне $1,18-0,65$ т/га.

Статистическая обработка урожайных данных позволила выявить закономерность формирования продуктивности озимой пшеницы в зависимости от применяемых систем удобрения и предшественника. Коэффициент множественной корреляции в зернопропашном севообороте составил 0,558-0,769 и в севообороте с травами 0,468-0,794 (таблица 7). 
Таблица 6 - Урожайность озимой пшеницы в зависимости от севооборота, предшественника и систем удобрения, сбалансированных по элементам питания, т/га

\begin{tabular}{|c|c|c|c|c|c|c|c|}
\hline \multirow[b]{2}{*}{$\begin{array}{l}\text { Система } \\
\text { удобрения }\end{array}$} & \multicolumn{4}{|c|}{ Предшественник } & \multirow{2}{*}{$\begin{array}{c}\text { Среднее } \\
\text { по систе- } \\
\text { ме удоб- } \\
\text { рения }\end{array}$} & \multicolumn{2}{|c|}{$\begin{array}{c}\text { Прибавка к } \\
\text { контролю }\end{array}$} \\
\hline & $\begin{array}{r}\text { кукуруза, } \\
\text { эспарцет }\end{array}$ & $\begin{array}{c}\text { озимая } \\
\text { пшеница }\end{array}$ & горох & \begin{tabular}{|c|} 
сахарная \\
свёкла
\end{tabular} & & т/га & $\%$ \\
\hline \multicolumn{8}{|c|}{ зернопропашной севооборот } \\
\hline $\begin{array}{l}\text { Без удобрений } \\
\text { (контроль) }\end{array}$ & 2,85 & 3,58 & 4,41 & 3,05 & 3,47 & & \\
\hline $\begin{array}{l}\text { Минимальная } \\
\text { доза NPK }\end{array}$ & 4,07 & 5,02 & 5,38 & 4,32 & 4,70 & 1,23 & 35,4 \\
\hline Средняя доза NPK & 5,56 & 6,52 & 6,31 & 5,52 & 5,88 & 2,41 & 69,4 \\
\hline $\begin{array}{l}\text { Повышенная } \\
\text { доза NPK }\end{array}$ & 6,20 & 6,16 & 6,30 & 6,24 & 6,22 & 2,75 & 79,2 \\
\hline Высокая доза NPK & 6,16 & 5,94 & 6,22 & 6,12 & 6,11 & 1,76 & 16,1 \\
\hline $\begin{array}{l}\text { Среднее по } \\
\text { предшественнику }\end{array}$ & 4,97 & 5,36 & 5,72 & 5,05 & 5,28 & & \\
\hline $\mathrm{HCP}_{05}$ & 0,42 & 0,47 & 0,52 & 0,43 & & & \\
\hline \multicolumn{8}{|c|}{ зернотравянопропашной севооборот } \\
\hline $\begin{array}{l}\text { Без удобрений } \\
\text { (контроль) }\end{array}$ & 5,41 & 4,11 & 4,65 & 3,34 & 4,38 & & \\
\hline $\begin{array}{l}\text { Минимальная } \\
\text { доза NРК }\end{array}$ & 6,17 & 5,11 & 5,42 & 4,43 & 5,28 & 0,90 & 20,5 \\
\hline Средняя доза NPK & 6,36 & 5,55 & 6,13 & 5,67 & 5,93 & 1,55 & 35,4 \\
\hline $\begin{array}{l}\text { Повышенная } \\
\text { доза NPK }\end{array}$ & 6,41 & 5,81 & 6,46 & 6,12 & 6,20 & 1,82 & 41,5 \\
\hline Высокая доза NPK & 6,43 & 5,82 & 6,37 & 6,06 & 6,17 & 1,79 & 40,9 \\
\hline $\begin{array}{l}\text { Среднее по } \\
\text { предшественнику }\end{array}$ & 6,16 & 5,28 & 5,81 & 5,12 & 5,59 & & \\
\hline $\mathrm{HCP}_{05}$ & 0,50 & 0,52 & 0,55 & 0,39 & & & \\
\hline
\end{tabular}


Таблица 7 - Корреляционная связь между урожайностью озимой пшеницы и системой удобрения в зависимости от предшественника и севооборота

\begin{tabular}{|c|c|c|c|c|}
\hline \multirow[b]{2}{*}{ Предшественник } & \multicolumn{2}{|c|}{ Коэффициент корреляции } & \multicolumn{2}{|c|}{ Доля влияния, \% } \\
\hline & $\begin{array}{c}\text { среднее, } \\
2000-2006 \text { гг. }\end{array}$ & $\begin{array}{c}\text { варьиро- } \\
\text { вание }\end{array}$ & $\begin{array}{c}\text { среднее, } \\
\text { 2000-2006 гг. }\end{array}$ & $\begin{array}{c}\text { варьиро- } \\
\text { вание }\end{array}$ \\
\hline \multicolumn{5}{|c|}{ зернопропашной севооборот } \\
\hline Кукуруза & 0,683 & $0,522-0,776$ & 48,7 & $27,2-60,2$ \\
\hline Озимая пшеница & 0,687 & $0,242-0,829$ & 47,3 & $5,8-68,8$ \\
\hline Горох & 0,558 & $0,101-0,842$ & 31,2 & $1,0-70,9$ \\
\hline Сахарная свёкла & 0,769 & $0,659-0,843$ & 59,2 & $43,4-71,1$ \\
\hline \multicolumn{5}{|c|}{ зернотравянопропашной севооборот } \\
\hline Эспарцет & 0,468 & $0,401-0,801$ & 28,1 & $16,1-53,1$ \\
\hline Озимая пшеница & 0,584 & $0,152-0,822$ & 38,7 & $2,3-67,6$ \\
\hline Горох & 0,500 & $0,246-0,910$ & 34,1 & $6,1-82,6$ \\
\hline Сахарная свёкла & 0,794 & $0,727-0,856$ & 63,2 & $53,0-73,3$ \\
\hline
\end{tabular}

При этом следует отметить, что доля влияния удобрений значительно варьировала по годам. Более высокой она была в годы с жесткими условиями периода вегетации. Средний показатель данного фактора в зернопропашном севообороте соответственно предшественника составил 31,2$59,2 \%$, в севообороте с многолетними травами - 28,1-63,2\%. Минимальные значения установлены по бобовым предшественникам.

Таким образом, использование в технологическом комплексе выращивания озимой пшеницы таких агроприёмов как подбор предшественника, размещение ее в севообороте и дифференцированное применение удобрений обеспечивает достоверно стабильно высокие урожаи зерна в пределах 6,0-6,5 т/га, что на 42-79 \% выше, чем при отказе от удобрений.

Статистическая обработка урожайных данных выявила общие закономерности в формировании продуктивности озимой пшеницы в зависимости от метеорологических условий произрастания и агротехнических 
приёмов возделывания. Прежде всего, между урожайностью и применяемыми агроприёмами, а также складывающимися в период вегетации погодными условиями, наблюдалась тесная корреляционная связь с коэффициентом множественной корреляции по предшественникам в зернопропашном севообороте 0,558-0,769 и в зернотравянопропашном 0,572-0,794. Анализ парной корреляции между урожайностью и показателями погодных условий, таких как сумма осадков, сумма среднесуточных положительных температур выше 5\% и среднесуточной температуры воздуха дало возможность определить направление и форму связей между этими показателями (таблица 8).

Так в процессе вегетации выявлена различная взаимосвязь между суммой осадков и величиной урожайности озимой пшеницы в зависимости от изучаемых систем удобрения. При этом теснота связи между рассматриваемыми элементами в начальный период вегетации посев-всходы отмечалась как очень слабая, а в процессе дальнейшей вегетации как средняя и высокая. По направлению эта связь была в период посев-всходы отрицательной $\mathrm{r}=-0,51-0,70$ и $-0,49-0,73$. В последующем она была в разной степени положительной от слабой до высокой. То есть при минимальном количестве осадков в осенний период урожайность озимой пшеницы снижалась. Доля влияния их соответственно предшественникам составила: по эспарцету и гороху 4,11-4,32 \%, кукурузе и сахарной свёкле - 8,72-8,89 \%, озимой пшенице - $16,69 \%$.

В весенне-летний период вегетации взаимосвязь между изучаемыми показателями колебалась в зернопропашном севообороте от средней отрицательной в период возобновления весенней вегетации $(\mathrm{r}=-0,51-0,70)$ до слабой положительной ( $\mathrm{r}=0,14-0,37$ ) в межфазный период молочнаявосковая спелость от слабой отрицательной $(\mathrm{r}=-0,03-0,25)$ до слабой положительной $(\mathrm{r}=0,04-0,10)$ в межфазный период восковая - полная спелость. 
Таблица 8 - Парная корреляция между погодными условиями и урожайностью озимой пшеницы в зернопропашном севообороте при различных системах удобрения (среднее по предшественникам)

\begin{tabular}{|c|c|c|c|c|c|}
\hline \multirow[b]{2}{*}{$\begin{array}{c}\text { Показатель метеороло- } \\
\text { гических условий }\end{array}$} & \multicolumn{5}{|c|}{ Межфазный период } \\
\hline & 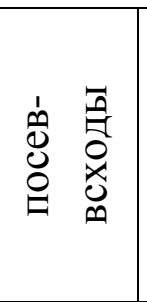 & 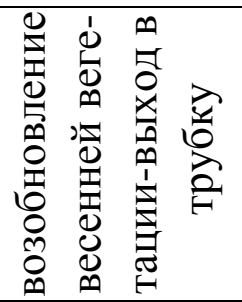 & 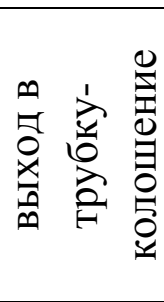 & 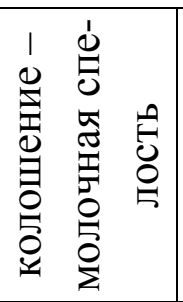 & 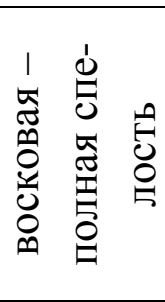 \\
\hline \multicolumn{6}{|c|}{ без удобрений } \\
\hline Сумма осадков, мм & $-0,16$ & $+0,75$ & $+0,53$ & $+0,46$ & $+0,10$ \\
\hline $\begin{array}{l}\text { Сумма положительных } \\
\text { температур }>5^{0} \mathrm{C}\end{array}$ & $-0,36$ & $+0,21$ & $+0,81$ & $+0,38$ & $+0,56$ \\
\hline $\begin{array}{l}\text { Среднесуточная темпе- } \\
\text { ратура воздуха, }{ }^{0} \mathrm{C}\end{array}$ & $+0,40$ & $-0,04$ & $-0,22$ & $+0,21$ & $-0,07$ \\
\hline \multicolumn{6}{|c|}{ минимальная доза NPK } \\
\hline Сумма осадков, мм & $-0,13$ & $+0,75$ & $+0,41$ & 0,57 & $+0,05$ \\
\hline $\begin{array}{l}\text { оложительных } \\
\text { ур }>5^{0} \mathrm{C}\end{array}$ & $-0,40$ & $+0,26$ & $+0,72$ & $+0,36$ & $+0,49$ \\
\hline $\begin{array}{l}\text { Среднесуточная темпе- } \\
\text { ратура воздуха, }{ }^{0} \mathrm{C}\end{array}$ & $+0,33$ & $-0,15$ & $-0,34$ & $-0,31$ & $+0,01$ \\
\hline \multicolumn{6}{|c|}{ средняя доза NPK } \\
\hline Сумма с & $-0,12$ & $+0,78$ & $+0,57$ & $+0,44$ & $-0,03$ \\
\hline $\begin{array}{l}\text { Сумма положительных } \\
\text { температур }>5^{0} \mathrm{C}\end{array}$ & $-0,15$ & $+0,27$ & $+0,77$ & $+0,40$ & $+0,49$ \\
\hline $\begin{array}{l}\text { Среднесуточная темпе- } \\
\text { ратура воздуха, }{ }^{0} \mathrm{C}\end{array}$ & $+0,41$ & $-0,09$ & $-0,46$ & $+0,15$ & $-0,08$ \\
\hline \multicolumn{6}{|c|}{ повышенная доза NPK } \\
\hline Сумма ос & $-0,11$ & $+0,69$ & $+0,59$ & $+0,46$ & $-0,20$ \\
\hline $\begin{array}{l}\text { Сумма положительных } \\
\text { температур }>5^{0} \mathrm{C}\end{array}$ & $-0,13$ & $+0,25$ & $+0,63$ & $+0,10$ & $+0,47$ \\
\hline $\begin{array}{l}\text { Среднесуточная темпе- } \\
\text { ратура воздуха, }{ }^{0} \mathrm{C}\end{array}$ & $+0,44$ & $-0,21$ & $-0,68$ & $+0,04$ & $-0,10$ \\
\hline \multicolumn{6}{|c|}{ высокая доза NPK } \\
\hline Сумма осадков, мм & $-0,07$ & $+0,68$ & $+0,59$ & $+0,38$ & $-0,25$ \\
\hline $\begin{array}{l}\text { Сумма положительных } \\
\text { температур }>5^{0} \mathrm{C}\end{array}$ & $-0,21$ & $+0,27$ & $+0,59$ & $+0,02$ & $+0,48$ \\
\hline $\begin{array}{l}\text { Среднесуточная темпе- } \\
\text { ратура воздуха, }{ }^{0} \mathrm{C}\end{array}$ & $+0,41$ & $-0,15$ & $-0,69$ & $+0,06$ & $-0,08$ \\
\hline
\end{tabular}


Положительная связь между урожайностью и суммой осадков в зернотравянопропашном севообороте имели место в межфазный период от возобновления весенней вегетации до выхода растений в трубку $(\mathrm{r}=0,77$ $0,85)$ и слабая в период колошения $(\mathrm{r}=0,29-0,46)$ (таблица 9).

Значительные различия в корреляционной связи по вариантам опыта между суммой осадков и урожайностью озимой пшеницы отмечены в межфазный период возобновления весенней вегетации-выход в трубку, где максимальный коэффициент ( $\mathrm{r}=0,77-0,86$ и $0,75-0,84)$ в обоих севооборотах отмечен при системах с парным сочетанием по элементам питания.

Наши исследования показали, что урожайность озимой пшеницы в значительной степени определялась взаимосвязью с суммой среднесуточных положительных температур. Однако эта взаимосвязь не является величиной постоянной, и значительно менялась по межфазным периодам вегетации культуры, что видимо, обусловлено биологией культуры. Так, в межфазный период посев-всходы нами отмечена отрицательная связь между этими показателями с коэффициентом парной корреляции -0,130,41 и -0,05-0,49. В межфазный период возобновление весенней вегетациивыход растений в трубку она была положительной $(\mathrm{r}=0,59-0,81$ и 0,680,84). В последующем корреляционная связь между величиной урожая и суммой положительных температур несколько ослабевала в фазе молочной спелости до $\mathrm{r}=0,10-0,38,0,16-0,46$, в фазу восковой спелости 0,32-0,46, 0,27-0,46 и возрастая в период полного созревания зерна 0,47-0,63.

С применением высоких норм удобрений величина урожая с суммой среднесуточных температур находилась в несколько более тесной зависимости $(\mathrm{r}=027-0,43)$ только в межфазный период возобновление весенней вегетации - выход растений в трубку. В остальные периоды более высоким этот показатель был на контроле и при системах удобрения с парным сочетанием по элементам питания. 
Таблица 9 - Парная корреляция между погодными условиями и урожайностью озимой пшеницы в зернотравянопропашном севообороте при различных системах удобрения (среднее по предшественникам)

\begin{tabular}{|c|c|c|c|c|c|}
\hline \multirow[b]{2}{*}{$\begin{array}{c}\text { Показатель } \\
\text { метеорологических } \\
\text { условий }\end{array}$} & \multicolumn{5}{|c|}{ Межфазный период } \\
\hline & 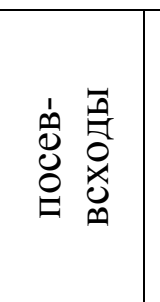 & 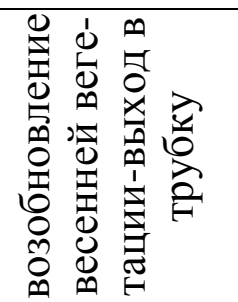 & 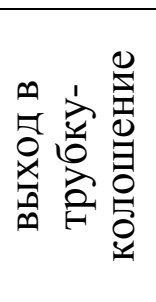 & 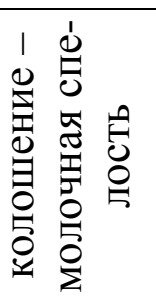 & 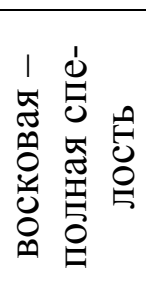 \\
\hline \multicolumn{6}{|c|}{ без удобрений } \\
\hline Сумма осадков, мм & $-0,18$ & $+0,78$ & $+0,55$ & $+0,39$ & $+0,08$ \\
\hline $\begin{array}{l}\text { Сумма положительных } \\
\text { температур }>5^{0} \mathrm{C}\end{array}$ & $-0,38$ & $+0,25$ & $+0,84$ & $+03,4$ & $+0,63$ \\
\hline $\begin{array}{l}\text { Среднесуточная темпе- } \\
\text { ратура воздуха, }{ }^{0} \mathrm{C}\end{array}$ & $+0,37$ & $+0,07$ & $-0,23$ & $-0,23$ & $-0,07$ \\
\hline \multicolumn{6}{|c|}{ минимальная доза NPK } \\
\hline Сумма осадков, мм & $-0,18$ & $+0,78$ & $+0,50$ & $+0,46$ & $+0,07$ \\
\hline $\begin{array}{l}\text { Сумма положительных } \\
\text { температур }>5^{0} \mathrm{C}\end{array}$ & $-0,39$ & $+0,26$ & $+0,81$ & $+0,40$ & $+0,50$ \\
\hline $\begin{array}{l}\text { Среднесуточная темпе- } \\
\text { ратура воздуха, }{ }^{0} \mathrm{C}\end{array}$ & $+0,37$ & $-0,05$ & $-0,27$ & $-0,23$ & $-0,08$ \\
\hline \multicolumn{6}{|c|}{ средняя доза NPK } \\
\hline Сумма осадков, мм & $-0,10$ & $+0,77$ & $+0,53$ & $+0,45$ & $+0,07$ \\
\hline $\begin{array}{l}\text { Сумма положительных } \\
\text { температур }>5^{0} \mathrm{C}\end{array}$ & $-0,16$ & $+0,25$ & $+0,74$ & $+0,26$ & $+0,48$ \\
\hline $\begin{array}{l}\text { Среднесуточная темпе- } \\
\text { ратура воздуха, }{ }^{0} \mathrm{C}\end{array}$ & $+0,40$ & $-0,13$ & $-0,46$ & $-0,15$ & $-0,07$ \\
\hline \multicolumn{6}{|c|}{ повышенная доза NPK } \\
\hline Сумма осадков, мм & $-0,10$ & $+0,85$ & $+0,44$ & $+0,43$ & $-0,21$ \\
\hline $\begin{array}{l}\text { Сумма положительных } \\
\text { температур }>5^{0} \mathrm{C}\end{array}$ & $-0,12$ & $+0,43$ & $+0,68$ & $+0,20$ & $+0,47$ \\
\hline $\begin{array}{l}\text { Среднесуточная темпе- } \\
\text { ратура воздуха, }{ }^{0} \mathrm{C}\end{array}$ & $+0,27$ & $-0,12$ & $-0,50$ & $-0,16$ & $-0,02$ \\
\hline \multicolumn{6}{|c|}{ высокая доза NPK } \\
\hline Сумма осадков, мм & $-0,02$ & $+0,83$ & $+0,52$ & $+0,29$ & $-0,25$ \\
\hline $\begin{array}{l}\text { Сумма положительных } \\
\text { температур }>5^{0} \mathrm{C}\end{array}$ & $-0,05$ & $+0,43$ & $+0,65$ & $+0,32$ & $+0,50$ \\
\hline $\begin{array}{l}\text { Среднесуточная темпе- } \\
\text { ратура воздуха, }{ }^{0} \mathrm{C}\end{array}$ & $+0,27$ & $+0,01$ & $-0,56$ & $-0,11$ & $-0,01$ \\
\hline
\end{tabular}


Положительная парная корреляция между урожайностью и среднесуточной температурой воздуха нами установлена только в межфазный период посев - всходы ( $\mathrm{r}=0,33-0,44$ и 0,27-0,40). В остальные периоды вегетации взаимосвязь между этими двумя показателями по своей направленности была слабой и средней отрицательной $(\mathrm{r}=-0,22-0,69$ и $-0,23$ 0,56), в фазу выход в трубку-колошение и отсутствовала в период от налива зерна до полной спелости ( $\mathrm{r}=-0,01-0,10$ и -0,02-0,09).

Величина этой связи в некоторой степени определялась изучаемыми приёмами агротехники. Полученные данные статистического анализа свидетельствуют, что посевы озимой пшеницы обеспеченные в полной мере элементами минерального питания в меньшей мере реагировали на изменение температурного режима, что подтверждается показателями парной корреляции между урожайностью и среднесуточной температурой воздуха.

И так, улучшение обеспеченности растений элементами минерального питания за счет внесения удобрений способствует увеличению количества новых побегов по сравнению с контролем на 20-390 шт./м². Установлена тесная корреляционная связь с коэффициентом 0,867-0,921 между урожайностью зерна озимой пшеницы и количеством сформировавшихся продуктивных стеблей.

Максимальные величины элементов структуры отмечены при системах удобрений с полным минеральным удобрением, при парных РК и NK. Урожайность озимой пшеницы на 8-15\% зависит от севооборота, на 15$18 \%$ - от предшественника и на 27-32\% - от удобрений.

\section{Список литературы}

1. Баршадская С.И. Продуктивность озимой пшеницы в северной зоне Краснодарского края / С.И. Баршадская, А.А. Романенко, А.А. Квашин.- Краснодар, 2010. $254 \mathrm{c}$.

2. Баршадская С.И. Эффективность выращивания различных сортов озимой пшеницы в условиях недостаточного увлажнения Краснодарского края / С.И. Баршадская, А.А. Квашин, К.Н. Горпинченко, Ф.И. Дерека //Политематический сетевой жур- 
нал Кубанского государственного аграрного университета. - 2016. - №120 - С. 13221336.

3. Баршадская С.И. Урожайность и качество зерна различных сортов озимой пшеницы в зависимости от предшественника удобрений и других приемов выращивания / С.И. Баршадская, Н.Н. Нещадим, А.А. Квашин //Политематический сетевой журнал Кубанского государственного аграрного университета. - 2016. - №120 - С. 13051321.

4. Василько В.П. Плодородие орошаемых и гидроморфных пахотных земель Северного Кавказа и путь его оптимизации: учебное пособие /В.П. Василько, В.Н. Герасименко, Н.Н. Нещадим. - Краснодар, 2010. - 118 с.

5. Горпинченко К.Н. Эффективность производства зерна в Краснодарском крае / К.Н. Горпинченко // АПК: Экономика, управление. - 2007, - №10. - С. 65-66.

6. Горпинченко К.Н. Экономическая эффективность применения перспективных агрегатов /Горпинченко К.Н. //Экономика сельского хозяйства России. - 2007. - №10. C. 31-32.

7. Горпинченко К.Н. Эффективность технологий выращивания озимой пшеницы / К.Н. Горпинченко // Экономика сельского хозяйства Россия. - 2007. - №5. - С.35-36.

8. Горпинченко К.Н. Эффективность производства зерна в Краснодарском крае /Горпинченко К.Н. //АПК: Экономика, управление. - 2007. -№10. -С. 65-66.

9. Горпинченко К.Н. Оценка эффективности и применения перспективных технологий выращивания зерна озимой пшеницы [Электронный ресурс] / К. Н. Горпинченко // Политематический сетевой электронный журнал Кубанского государственного аграрного университета. - 2007. - №34(10). - С. 102-108. - Режим доступа: http://ej.kubagro.ru/2007/10/pdf/13.pdf.

10. Горпинченко К.Н. Экономическая оценка и обоснование направлений снижения ресурсоемкости производства зерна озимой пшеницы: Автореф. ... канд. эк. наук./ К.Н. Горпинченко.- Краснодар, 2008.

11. Горпинченко К.Н. Экономическая эффективность производства и качества зерна в зависимости от приемов выращивания и технологий / К.Н. Горпинченко // Труды Кубанского государственного аграрного университета. - 2008. - №10. - С. 52-57.

12. Горпинченко К.Н. Уровень ресурсоемкости производства зерна в сельскохозяйственных организациях Краснодарского края / К.Н. Горпинченко // Известия Самарской государственной сельскохозяйственной академии. - 2008. - №2. - С. 102106.

13. Горпинченко К.Н. Особенности прогнозирования производства зерна/К.Н. Горпинченко// Экономика сельскохозяйственных и перерабатывающих предприятий. 2012. -№4. - С. 46-49.

14. Горпинченко К.Н. Экономическая оценка влияния инвестиций на эффективность зернового производства / К.Н. Горпинченко // Известия Оренбургского государственного аграрного университета. - 2013. - №1(39). - С. 118-121.

15. Горпинченко К.Н. Технологический фактор научно-технического прогресса зернового производства /К.Н. Горпинченко// Известия Оренбургского государственного аграрного университета. - 2013. - №6 (116). - С. 171-173.

16. Горпинченко К.Н. Техническая модернизация зернового производства в Краснодарском крае /К.Н. Горпинченко// Наука и Мир. - 2013. -№2(2). - С. 85-88.

17. Горпинченко К.Н. Системы показателей инновационного развития в зерновом производстве/ К.Н. Горпинченко// Вестник АПК Ставрополья. - 2013. -№2(10). С. $152-156$.

18. Горпинченко К.Н. Проблемы развития инновационного процесса в зерновом производстве[Электронный ресурс] /К.Н. Горпинченко//Политематический сетевой 
электронный научный журнал Кубанского государственного аграрного университета. 2013. -№86. - С. 634-649.- Режим доступа: http://ej.kubagro.ru/2013/02/pdf/38.pdf.

19. Горпинченко К.Н. Методология анализа и эффективности инноваций в зерновом производстве (часть 2)/ К.Н. Горпинченко// Экономика сельскохозяйственных и перерабатывающих предприятий. - 2014. -№1, С. 39-41.

20. Горпинченко К.Н. Методология формирования организационноэкономического механизма управления инновационным процессом в зерновом производстве / К.Н. Горпинченко // Труды Кубанского государственного аграрного университета. - 2014 - №48 - С. 14-17.

21. Горпинченко К.Н. Методические рекомендации по разработке программы развития инновационного процесса в зерновом производстве региона / К.Н. Горпинченко // Политематический сетевой журнал Кубанского государственного аграрного университета. - 2014. - №101. - С. 1598-1611.

22. Квашин А.А. Плодородие чернозема обыкновенного и продуктивность сельскохозяйственных культур /А.А. Квашин, С.И. Баршадская, Ф.И. Дерека//Плодородие. - №2, - 2011. - С. 36-39.

23. Квашин А.А. Сорт - основа высоких урожаев озимой пшеницы в Краснодарском крае /А.А. Квашин// Земледелие. - №3. - 2011. - С. 47-48.

24. Кравцов А.М. Агроэкологические основы технологии выращивания сахарной свеклы и озимой пшеницы в зернотравянопропашном севообороте на выщелоченном черноземе Западного Предкавказья: автореф. дис. ... д-ра с.-х. наук. - Краснодар, 2001. $-52 \mathrm{c}$.

25. Малюга Н.Г. Влияние приемов выращивания на содержание основных элементов питания, тяжелых металлов в почве и урожайность зерна озимой пшеницы в центральной зоне Краснодарского края /Н.Г. Малюга, Н.Н. Нещадим, С.В. Гаркуша, Г.Ф. Петрик //Труды Кубанского государственного аграрного университета. 2012.№35. -С. 135-142.

26. Минеев В.Г. Удобрение зерновых культур / В.Г. Минеев, М.М. Ивлев. - М.: Россельхозиздат, 1980, - 173 с.

27. Нещадим Н.Н. Оценка действия поликомпонентных удобрений в условиях Западного Предкавказья / Н.Н. Нещадим, Л.М. Онищенко, С.В. Есипенко//Труды Кубанского государственного аграрного университета. -2012.- №35, С. 208-213.

28. Нещадим Н.Н. Регуляторы роста растений и факторы физического воздействия при возделывании сельскохозяйственных культур в условиях Кубани: автореф. ... д-р с.-х. наук / Н.Н. Нещадим. - Кубанский государственный аграрный университет, Краснодар. - 1997. - 48 с.

29. Нещадим Н.Н. Современные проблемы качества зерна /Н.Н. Нещадим, К.Н. Горпинченко, А.А. Квашин// Труды Кубанского государственного аграрного университета. - 2012. - №35. -С. 338-342.

30. Прудников А.Г. Совершенствование системы семеноводства зерновых культур в Краснодарском крае [Электронный ресурс] / А.Г. Прудников, К.Н. Горпинченко // Политематический сетевой журнал Кубанского государственного аграрного университета. - 2016. - №115. - С. 894-907. - Режим доступа: http://ej.kubagro.ru/2016/01/pdf/56.pdf.

31. Прудников А.Г. Формирование затрат на создание нового сорта (гибрида) зерновых культур /А.Г. Прудников, К.Н. Горпинченко// В мире научных открытий. 2013. - №8.1 (44). - С. 293-305.

32. Прудников А.Г. Современные проблемы качества зерна /А.Г. Прудников, К.Н. Горпинченко, А.А. Квашин// Труды Кубанского государственного аграрного университета. - 2012. - №83. - С. 747-770. 
33. Романенко А.А. Новая сортовая политика и сортовая агротехника озимой пшеницы / А.А. Романенко, Л.А. Беспалова, И.Н. Кудряшов, И.Б. Аблова. - Краснодар, 2005. $-220 \mathrm{c}$.

34. Система земледелия Краснодарского края на агроландшафной основе /А.Н. Коробко, С.Ю. Орленко, А.И. Трубилин, Н.Н. Нещадим и др. - Краснодар, 2015. - 352 с.

35. Шеуджен А.Х. Органическое вещество почвы и его экологические функции /А.Х. Шеуджен, Н.Н. Нещадим, Л.М. Онищенко // Краснодар, 2011. - 113 с.

36. Штомпель Ю.А. Оценка качества почв, пути воспроизводства плодородия их и рационального использования: учебник /Ю.А. Штомпель, Н.Н. Нещадим, И.А. Лебедовский // Краснодар, -2009. - 315 с.

\section{References}

1. Barshadskaja S.I. Produktivnost' ozimoj pshenicy v severnoj zone Krasno-darskogo kraja / S.I. Barshadskaja, A.A. Romanenko, A.A. Kvashin. - Krasnodar, 2010. - 254 s.

2. Barshadskaja S.I. Jeffektivnost' vyrashhivanija razlichnyh sortov ozimoj pshenicy v uslovijah nedostatochnogo uvlazhnenija Krasnodarskogo kraja / S.I. Barshad-skaja, A.A. Kvashin, K.N. Gorpinchenko, F.I. Dereka //Politematicheskij setevoj zhur-nal Kubanskogo gosudarstvennogo agrarnogo universiteta. - 2016. - №120 - S. 1322-1336.

3. Barshadskaja S.I. Urozhajnost' i kachestvo zerna razlichnyh sortov ozimoj pshenicy $\mathrm{v}$ zavisimosti ot predshestvennika udobrenij i drugih priemov vyrashhiva-nija / S.I. Barshadskaja, N.N. Neshhadim, A.A. Kvashin //Politematicheskij setevoj zhurnal Kubanskogo gosudarstvennogo agrarnogo universiteta. - 2016. - №120 - S. 1305-1321.

4. Vasil'ko V.P. Plodorodie oroshaemyh i gidromorfnyh pahotnyh zemel' Severnogo Kavkaza i put' ego optimizacii: uchebnoe posobie / V.P. Vasil'ko, V.N. Gerasimenko, N.N. Neshhadim. - Krasnodar, 2010. - 118 s.

5. Gorpinchenko K.N. Jeffektivnost' proizvodstva zerna v Krasnodarskom krae / K.N. Gorpinchenko // APK: Jekonomika, upravlenie. - 2007, - №10. - S. 65-66.

6. Gorpinchenko K.N. Jekonomicheskaja jeffektivnost' primenenija perspektiv-nyh agregatov /Gorpinchenko K.N. // Jekonomika sel'skogo hozjajstva Rossii. - 2007. - №10. - S. 31-32.

7. Gorpinchenko K.N. Jeffektivnost' tehnologij vyrashhivanija ozimoj pshenicy / K.N. Gorpinchenko // Jekonomika sel'skogo hozjajstva Rossija. - 2007. - №5. - S.35-36.

8. Gorpinchenko K.N. Jeffektivnost' proizvodstva zerna v Krasnodarskom krae /Gorpinchenko K.N. // APK: Jekonomika, upravlenie. - 2007. - №10. - S. 65-66.

9. Gorpinchenko K.N. Ocenka jeffektivnosti i primenenija perspektivnyh tehno-logij vyrashhivanija zerna ozimoj pshenicy [Jelektronnyj resurs] / K. N. Gorpinchenko // Politematicheskij setevoj jelektronnyj zhurnal Kubanskogo gosudarstvennogo agrarnogo universiteta. - 2007. - №34(10). - S. 102-108. - Rezhim dostupa: http://ej.kubagro.ru/2007/10/pdf/13.pdf.

10. Gorpinchenko K.N. Jekonomicheskaja ocenka i obosnovanie napravlenij snizhenija resursoemkosti proizvodstva zerna ozimoj pshenicy: Avtoref. ... kand. jek. nauk./ K.N. Gorpinchenko. - Krasnodar, 2008.

11. Gorpinchenko K.N. Jekonomicheskaja jeffektivnost' proizvodstva i kachestva zerna v zavisimosti ot priemov vyrashhivanija i tehnologij / K.N. Gorpinchenko // Trudy Kubanskogo gosudarstvennogo agrarnogo universiteta. - 2008. - №10. - S. 52-57.

12. Gorpinchenko K.N. Uroven' resursoemkosti proizvodstva zerna v sel'skohozjajstvennyh organizacijah Krasnodarskogo kraja / K.N. Gorpinchenko // Izvestija Samarskoj gosudarstvennoj sel'skohozjajstvennoj akademii. - 2008. - №2. - S.102-106. 
13. Gorpinchenko K.N. Osobennosti prognozirovanija proizvodstva zerna / K.N. Gorpinchenko // Jekonomika sel'skohozjajstvennyh i pererabatyvajushhih predprijatij. - 2012. - №4. - S.46-49.

14. Gorpinchenko K.N. Jekonomicheskaja ocenka vlijanija investicij na jeffektivnost' zernovogo proizvodstva / K.N. Gorpinchenko // Izvestija Orenburgskogo gosudar-stvennogo agrarnogo universiteta. - 2013. - №1(39). - S. 118-121.

15. Gorpinchenko K.N. Tehnologicheskij faktor nauchno-tehnicheskogo progressa zernovogo proizvodstva / K.N. Gorpinchenko // Izvestija Orenburgskogo gosudarstvennogo agrarnogo universiteta. - 2013. - №6 (116). - S. 171-173.

16. Gorpinchenko K.N. Tehnicheskaja modernizacija zernovogo proizvodstva v Krasnodarskom krae / K.N. Gorpinchenko // Nauka i Mir. - 2013. - №2(2). - S. 85-88.

17. Gorpinchenko K.N. Sistemy pokazatelej innovacionnogo razvitija v zernovom proizvodstve/ K.N. Gorpinchenko // Vestnik APK Stavropol'ja. - 2013. - №2(10). - S. 152156.

18. Gorpinchenko K.N. Problemy razvitija innovacionnogo processa v zerno-vom proizvodstve [Jelektronnyj resurs] / K.N. Gorpinchenko // Politematicheskij se-tevoj jelektronnyj nauchnyj zhurnal Kubanskogo gosudarstvennogo agrarnogo universiteta. - 2013. - №86. - S. 634-649. - Rezhim dostupa: http://ej.kubagro.ru/2013/02/pdf/38.pdf.

19. Gorpinchenko K.N. Metodologija analiza i jeffektivnosti innovacij v zernovom proizvodstve (chast' 2) / K.N. Gorpinchenko // Jekonomika sel'skohozjajstvennyh i pererabatyvajushhih predprijatij. - 2014. - №1, S. 39-41.

20. Gorpinchenko K.N. Metodologija formirovanija organizacionnojekonomicheskogo mehanizma upravlenija innovacionnym processom $\mathrm{v}$ zernovom proizvodstve / K.N. Gorpinchenko // Trudy Kubanskogo gosudarstvennogo agrarnogo universiteta. - 2014 - №48 - S. 14-17.

21. Gorpinchenko K.N. Metodicheskie rekomendacii po razrabotke programmy razvitija innovacionnogo processa v zernovom proizvodstve regiona / K.N. Gorpin-chenko // Politematicheskij setevoj zhurnal Kubanskogo gosudarstvennogo agrarnogo universiteta. 2014. - №101. - S. 1598-1611.

22. Kvashin A.A. Plodorodie chernozema obyknovennogo i produktivnost' sel'skohozjajstvennyh kul'tur / A.A. Kvashin, S.I. Barshadskaja, F.I. Dereka // Plo-dorodie. - №2, 2011. - S.36-39.

23. Kvashin A.A. Sort - osnova vysokih urozhaev ozimoj pshenicy v Krasno-darskom krae / A.A. Kvashin // Zemledelie. - №3. - 2011. - S.47-48.

24. Kravcov A.M. Agrojekologicheskie osnovy tehnologii vyrashhivanija saharnoj svekly i ozimoj pshenicy $\mathrm{v}$ zernotravjanopropashnom sevooborote na vyshhelochennom chernozeme Zapadnogo Predkavkaz'ja: avtoref. dis. ... d-ra s.-h. nauk. - Krasnodar, 2001. $52 \mathrm{~s}$.

25. Maljuga N.G. Vlijanie priemov vyrashhivanija na soderzhanie osnovnyh jelementov pitanija, tjazhelyh metallov $\mathrm{v}$ pochve $\mathrm{i}$ urozhajnost' zerna ozimoj pshenicy $\mathrm{v}$ central'noj zone Krasnodarskogo kraja / N.G. Maljuga, N.N. Neshhadim, S.V. Garkusha, G.F. Petrik // Trudy Kubanskogo gosudarstvennogo agrarnogo universiteta. 2012. - №35. - S.135142.

26. Mineev V.G. Udobrenie zernovyh kul'tur / V.G. Mineev, M.M. Ivlev. - M.: Rossel'hozizdat, 1980, - $173 \mathrm{~s}$.

27. Neshhadim N.N. Ocenka dejstvija polikomponentnyh udobrenij v uslovijah Zapadnogo Predkavkaz'ja / N.N. Neshhadim, L.M. Onishhenko, S.V. Esipenko // Trudy Kubanskogo gosudarstvennogo agrarnogo universiteta. - 2012. - №35, S. 208-213. 
28. Neshhadim N.N. Reguljatory rosta rastenij i faktory fizicheskogo vozdej-stvija pri vozdelyvanii sel'skohozjajstvennyh kul'tur v uslovijah Kubani: avtoref. ... d-r s.h. nauk / N.N. Neshhadim. - Kubanskij gosudarstvennyj agrarnyj universitet, Krasnodar. - 1997. - 48 s.

29. Neshhadim N.N. Sovremennye problemy kachestva zerna / N.N. Neshhadim, K.N. Gorpinchenko, A.A. Kvashin // Trudy Kubanskogo gosudarstvennogo agrarnogo universiteta. - 2012. - №35. - S. 338-342.

30. Prudnikov A.G. Sovershenstvovanie sistemy semenovodstva zernovyh kul'tur v Krasnodarskom krae [Jelektronnyj resurs] / A.G. Prudnikov, K.N. Gorpin-chenko // Politematicheskij setevoj zhurnal Kubanskogo gosudarstvennogo agrarnogo universiteta. - 2016. - №115. - S. 894-907. - Rezhim dostupa: http://ej.kubagro.ru/2016/01/pdf/56.pdf.

31. Prudnikov A.G. Formirovanie zatrat na sozdanie novogo sorta (gibrida) zernovyh kul'tur / A.G. Prudnikov, K.N. Gorpinchenko // V mire nauchnyh otkrytij. - 2013. - №8.1 (44). - S. 293-305.

32. Prudnikov A.G. Sovremennye problemy kachestva zerna / A.G. Prudnikov, K.N. Gorpinchenko, A.A. Kvashin // Trudy Kubanskogo gosudarstvennogo agrarnogo universiteta. - 2012. - №83. - S. 747-770.

33. Romanenko A.A. Novaja sortovaja politika i sortovaja agrotehnika ozimoj pshenicy / A.A. Romanenko, L.A. Bespalova, I.N. Kudrjashov, I.B. Ablova. - Krasno-dar, 2005. $220 \mathrm{~s}$

34. Sistema zemledelija Krasnodarskogo kraja na agrolandshafnoj osnove /A.N. Korobko, S.Ju. Orlenko, A.I. Trubilin, N.N. Neshhadim i dr. - Krasnodar, 2015. - 352 s.

35. Sheudzhen A.H. Organicheskoe veshhestvo pochvy i ego jekologicheskie funkcii / A.H. Sheudzhen, N.N. Neshhadim, L.M. Onishhenko // Krasnodar, 2011. - 113 s.

36. Shtompel' Ju.A. Ocenka kachestva pochv, puti vosproizvodstva plodorodija ih i racional'nogo ispol'zovanija: uchebnik / Ju.A. Shtompel', N.N. Neshhadim, I.A. Lebedovskij // Krasnodar, - 2009. - 315 s. 